\title{
Analysis of Infusion and Ethanol Extract of Tamarindus indica L, Scurrula Sp, Mimosa pudica D of Fresh and Dry as Amylase Enzyme Inhibitor
}

\author{
Analisis Infusa dan Ekstrak Etanol \\ Tamarindus indica L, Scurrula Sp, Mimosa pudica D \\ Segar dan kering sebagai inhibitor enzim amilase
}

\author{
Silvera Devi Sy ${ }^{1}$, Musyirna Rahmah Nst ${ }^{2}$, Ninuk Rodhiatul Jannah ${ }^{1}$ \\ ${ }^{1}$ Jurusan Kimia Fakultas Matematika dan Ilmu Pengetahuan Alam, \\ Universitas Riau, Pekanbaru 28293 \\ ${ }^{2}$ Sekolah Tinggi Ilmu Farmasi Riau, Pekanbaru, 28293 \\ silveradevi.sy@gmail.com
}

\begin{abstract}
$\alpha$-amilase is one of digestive enzyme that hydrolize starch to maltose by $\alpha$-glukosidase and degradation to form a glucose and continue with blood adsorption through villi of small intestine. Consomption of acarbose drug is one of ways for diabetic treatment to inhibit the activity of $\alpha$ amilase. Tamarind leaves (Tamarindus indica L) herbal benalu api (Scurrula Sp) and herbal putri malu (Mimosa pudica D) regularly used as medical plant with activity of antidiabetic medicine. The aims of this studies was to analyze the potency of three medical plant with form of infusa and ethanol extract from fresh or dried plant to inhibit activity of $\alpha$-amilase and akarbose used as positive control. Inhibition potency of sample against activity of $\alpha$-amilase were determine base on maltose produced by of starch hydrolysis $\alpha$-amilase to reduction dinitrosalicylic acid become 3amino-5-nitrosalicylic acid and the absorbance were measured with spektrofotometer at $530 \mathrm{~nm}$. Resulted of percentage inhibition against activity of $\alpha$-amilase were herbal infusa from dried benalu api $85.58 \pm 2,93 \%$, infusa of fresh putri malu $87.40 \pm 1,81 \%$, and the dried $98,85 \pm 0,66 \%$. These results did not significancy different with inhibition of akarbose $93.89 \pm 0,02 \%$. Infusa herbal of dried benalu api, fresh and dried putri malu were potential cover for acarbose to used as alternative medicine.
\end{abstract}

Keywords: $\alpha$-amilase, $\%$ inhibition, herbal benalu api, herbal putri malu, tamarind.

\begin{abstract}
ABSTRAK
$\alpha$-amilase merupakakan salah satu enzim pencernaan yang menghidrolisis amilum menjadi maltosa, oleh $\alpha$-glukosidase didegradasi menghasilkan glukosa, kemudian diadsorbsi oleh darah melalui villi usus halus. Salah satu cara untuk mengurangi kadar glukosa di usus halus bagi penderita diabetes mellitus adalah dengan mengkonsumsi obat acarbose untuk menghambat aktivitas $\alpha$-amilase. Obat tradisioanal yang diduga berkhasiat antidiabetes dan sering dikonsumsi masyarakat antara lain adalah daun asam jawa (Tamarindus indica $\mathrm{L}$ ), herbal benalu api (Scurrula $\mathrm{Sp}$ ) dan herbal putri malu (Mimosa pudica D). Penelitian ini bertujuan untuk menganalisis potensi ketiga tanaman tersebut secara in vitro dalam bentuk infusa dan ekstrak etanol dari tanaman segar maupun yang sudah dikeringkan untuk menghambat aktivitas $\alpha$-amilase dan sebagai kontrol positif digunakan obat akarbose. Kemampuan inhibisi sampel terhadap aktivitas $\alpha$-amilase ditentukan berdasarkan kemampuan maltosa hasil hidrolisis amilum oleh $\alpha$-amilase untuk mereduksi asam dinitro salisilat menjadi asam 3-amino-5-nitrosalisilat dan absorbansinya diukur menggunakan spetrofotometer pada $530 \mathrm{~nm}$. Nilai \% inhibisi terhadap aktivitas $\alpha$-amilase dari infusa herbal benalu api kering sebesar $85.58 \pm 2,93 \%$ infusa herbal putri malu segar $87.40 \pm 1,81 \%$ dan yang keringnya $98.85 \pm 0,66 \%$. Hasil tersebut secara statistik tidak berbeda secara signifikan dengan
\end{abstract}


inhibisi obat akarbose $93.89 \pm 0,02 \%$. Infusa herbal benalu api kering, infusa herbal putri malu segar dan kering berpotensi digunakan sebagai obat alternatif penganti obat acarbose (glucobay $\left.{ }^{\circledR}\right)$ Kata kunci : $\alpha$-amilase, \% inhibisi, asam jawa, herbal benalu api, herbal putri malu

\section{PENDAHULUAN}

Indonesia adalah negara yang mempunyai berbagai macam jenis tanaman obat dengan khasiat yang sangat beragam (Kementrian Kehutanan RI. 2010). Secara tradisional, tanaman berkhasiat obat yang telah digunakan oleh masyarakat antara lain, yaitu daun asam jawa (Tamarindus indica L), herbal benalu api (Scurrula Sp) dan herbal putri malu (Mimosa pudica D). Tanaman berkhasiat obat ini memiliki kandungan senyawa kimia yang berbeda, daun asam jawa mengandung dhlobatanin, sedangkan buahnya mengandung senyawa kimia asam sitrat, asam suksinat, asam tartarat dan pektin (Tampubolon. 1995). Senyawa kimia pada herbal benalu antara lain adalah alkaloid, glukosida, flavonoid, saponin, quercetin, $\beta$-amyrin dan asam oleanoat (Wijayakusuma, 2011), dan pada putri malu ditemukan tanin, mimosin, dan asam pipekolinat (Dalimartha, 2007). Ketiga jenis tanaman ini dapat dimanfaatkan untuk obat alternatif dan diduga mampu mengatasi penyakit diabetes mellitus tipe 2. Kadar glukosa darah prediabetes (kondisi seseorang beresiko tinggi terkena diabetes) yaitu sekitar 100$140 \mathrm{mg} / \mathrm{dL}$ dan apabila $>200 \mathrm{mg} / \mathrm{dL}$, didiagnosa diabetes mellitus karena kadar glukosa darah normal yaitu 60-100 mg/dL (Kee \& Hayes, 1996).

Obat yang saat ini umum digunakan untuk diabetes mellitus yang mampu menginhibisi aktivitas enzim $\alpha$-amilase dan $\alpha$-glukosidase adalah acarbose (Gambar 1). Acarbose adalah suatu oligosakarida yang diperoleh dari proses fermentasi mikroorganisme, berupa serbuk berwarna putih dengan berat molekul 645,6 bersifat larut dalam air dan rumus molekulnya adalah $\mathrm{C}_{25} \mathrm{H}_{43} \mathrm{NO}_{18}$.

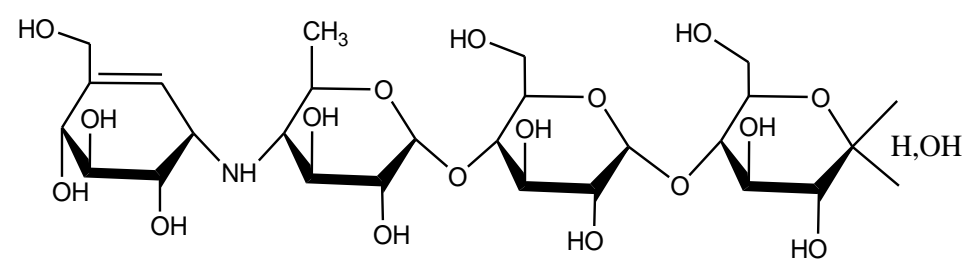

Gambar 1. Struktur kimia akarbosa (Robyt, 2005)

Obat acarbose ini hanya bekerja menginhibisi aktivitas enzim $\alpha$-amilase dan enzim $\alpha$-glukosidase di usus halus. Acarbose tidak dapat berdifusi atau diserap 
oleh darah sehingga apabila di konsumsi dalam waktu yang relatif lama akan memberikan efek negatif antara lain terjadinya gangguan kesehatan lambung, menghasilkan gas, lebih sering flatus dan dalam beberapa kasus menyebabkan diare (Hakim, 2011). Oleh karena itu, usaha untuk mencari obat tradisional alternatif pengganti acarbose sampai saat ini terus berlanjut.

\section{BAHAN DAN METODE}

Daun asam jawa, herbal benalu api, herbal putri malu dijadikan sampel dalam bentuk segar dan yang sudah dikeringkan. Masing-masing sampel dibuat dalam bentuk infusa dengan konsentrasi 50\% ektrak kental etanol konsentrasi $0,1 \%$ dan sebagai control positif adalah acarbose dengan konsentrasi $0,1 \%$.

Pembuatan infusa dilakukan dengan cara masing-masing sampel (segar atau kering) direbus dengan air di dalam panci infusa selama 15 menit pada suhu $90^{\circ} \mathrm{C}$. Selanjutnya, masing-masing rebusan tanaman ini didinginkan pada suhu ruang dan kemudian disaring (infusa). Ekstrak kental etanol dari masing-masing sampel diperoleh dengan cara maserasi dengan pelarut etanol 96\% selama 3 hari, kemudian disaring. Masing-masing ekstrak kemudian dipekatkan menggunakan rotary evaporator. Infusa dan ekstrak kental etanol ini selanjutnya ditentukan \% inhibisinya terhadap enzim $\alpha$-amilase menggunakan metode DNS. Maltosa hasil hidrolisis amilum (substrat) oleh $\alpha$-amilase akan mereduksi DNS (kuning) (Gambar 2) menjadi asam 3-amino-5- Dinitrosalisilat (orange kemerahan) dan absorbansinya diukur menggunakan microplate reader 96 well pada $\lambda 530 \mathrm{~nm}$.

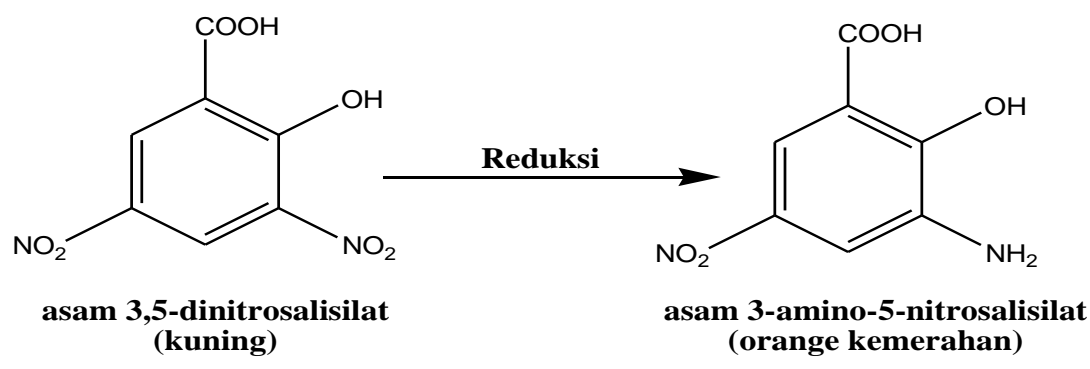

Gambar 2. Reaksi reduksi DNS (Sastrohamidjojo\& Hardjono, 2005) 
Tabel 1. Sistem reaksi uji inhibisi sampel terhadap aktivitas enzim $\alpha$-amilase

\begin{tabular}{|c|c|c|c|c|c|c|}
\hline \multirow{2}{*}{ Reagen } & \multicolumn{6}{|c|}{ Volume $(\mu \mathrm{l})$} \\
\hline & $\mathbf{B}_{1}$ & $\mathbf{B}_{0}$ & $S_{1}$ & $S_{0}$ & $\mathbf{A}_{1}$ & $\mathbf{A}_{0}$ \\
\hline Sampel & - & - & 150 & 150 & 150 & 150 \\
\hline Aqua dm & 400 & 800 & 250 & 650 & 250 & 650 \\
\hline Enzim & 400 & - & 400 & - & 400 & - \\
\hline \multicolumn{7}{|c|}{ Inkubasi 30 menit, suhu $37^{\circ} \mathrm{C}$} \\
\hline Substrat & \multicolumn{4}{|c|}{ Inkubasi 40 menit, suhu $37^{\circ} \mathrm{C}$} & 50 & 50 \\
\hline DNS & 25 & 25 & 25 & 25 & 25 & 25 \\
\hline
\end{tabular}

Keterangan :
$\mathrm{S}_{1}$ : Sampel
$\mathrm{B}_{1}$ : Blanko
$\mathrm{A}_{1}:$ Acarbose
$\mathrm{S}_{0}:$ Kontrol sampel
$\mathrm{B}_{0}$ : Kontrol blanko
Ao : kontrol acarbose

Persen inhibisi dari masing-masing infusa dan ekstrak etanol dari sampel dapat dihitung dengan rumus

$$
\% \text { inhibisi }=\frac{(\mathrm{B} 1-\mathrm{B} 0)-(\mathrm{S} 1-\mathrm{S} 0)}{\mathrm{B} 1-\mathrm{B} 0} \times 100
$$

Data hasil \% inhibisi dari masing-masing infusa dan ekstrak etanol ini di uji secara statistik menggunakan one-way analysis of variance (ANOVA) dan dilanjutkan dengan metode Duncan multiple test pada signifkansi 0,05 $(P<0,05)$.

\section{HASIL DAN PEMBAHASAN}

Data persen (\%) inhibisi secara in vitro dari masing-masing infusa dan ekstrak kental etanol dan kontrol positif akarbose terhadap aktivitas enzim $\alpha$ amilase setelah dilakukan uji secara statistik menggunakan metode Duncan multiple test pada signifkansi 0,05 hasilnya dapat dilihat pada Tabel 2.

Maserasi dilakukan menggunakan pelarut etanol, pemilihan pelarut disebabkan karena etanol mudah menguap, sehingga lebih mudah di pekatkan dan setelah proses penguapan, toksisitasnya relatif rendah (Samuelsson, 2000). Teknik infusa dipilih karena masyarakat Indonesia pada umumnya mengolah tanaman obat secara konvesional yaitu dengan cara merebusnya menggunakan air. Air mempunyai kemampuan mengekstrak senyawa polar yang terdapat di dalam tanaman berkhasiat obat lebih baik dibandingkan dengan etanol. 
Tabel 2. Hasil uji statistik inhibisi sampel terhadap aktivitas $\alpha$-amilase

\begin{tabular}{|c|c|c|c|c|}
\hline No. & Nama Tanaman & Jenis sampel & Metode & $\begin{array}{l}\text { \% Inhibisi sampel terhadap } \\
\alpha \text {-amilase }\end{array}$ \\
\hline \multirow[t]{2}{*}{1.} & \multirow[t]{2}{*}{ Daun Asan Jawa } & Segar & $\begin{array}{l}\text { Infusa } \\
\text { etanol } \\
\text { infusa }\end{array}$ & $\begin{array}{l}-176,57 \pm 0,00^{\mathrm{a}} \\
43,95 \pm 5,49^{\mathrm{cd}} \\
0,69 \pm 21,41^{\mathrm{abc}}\end{array}$ \\
\hline & & Kering & etanol & $23,80 \pm 8,39^{\mathrm{ac}}$ \\
\hline \multirow[t]{2}{*}{2.} & \multirow[t]{2}{*}{ Herbal Benalu Api } & Segar & $\begin{array}{l}\text { infusa } \\
\text { etanol } \\
\text { infusa }\end{array}$ & $\begin{array}{l}-8,72 \pm 30,54^{\mathrm{ab}} \\
53,84 \pm 3,29^{\mathrm{cd}} \\
\mathbf{8 5 , 5 8} \pm \mathbf{2 , 9 3}\end{array}$ \\
\hline & & Kering & etanol & $42,12 \pm 20,45^{b c d}$ \\
\hline \multirow{4}{*}{3.} & \multirow{4}{*}{ Herbal Putri Malu } & & infusa & $87,40 \pm 1,81^{\mathrm{e}}$ \\
\hline & & Segar & etanol & $45,05 \pm 14,02^{\mathrm{cd}}$ \\
\hline & & & infusa & $98,85 \pm 0,66^{\mathrm{e}}$ \\
\hline & & Kering & etanol & $32,41 \pm 12,63^{\text {bcd }}$ \\
\hline 4 & Akarbose & & & $93,89 \pm 0,02^{\mathrm{e}}$ \\
\hline
\end{tabular}

Data hasil uji statistik inhibisi sampel terhadap aktivitas $\alpha$-amilase pada Tabel 2 menunjukkan bahwa \% inhibisi untuk masing-masing ekstrak etanol dari dari daun asam jawa, herbal benalu api, herbal putri malu (segar atau kering) terhadap enzim $\alpha$-amilase masing-masing relatif lebih rendah dari akarbose yaitu berkisar antara $23,80 \pm 8,39 \%$ s/d 53,84 $\pm 3,29 \%$. Persen inhibisi infusa terhadap aktivitas $\alpha$-amilase relatif lebih tinggi dibandingkan dari ekstrak kental etanol, yaitu untuk herbal benalu api kering \% inhibisinya adalah 85,58 $\pm 2,93 \%$, infusa herbal putri malu segar 98,85 $\pm 0,66 \%$ dan yang keringnya 85,58 $\pm 2,93 \%$. Persen inhibisi dari ke tiga infusa ini setelah diuji secara statistik ternyata tidak berbeda secara signifikan ( $\mathrm{P}>0,05)$ dengan \% inhibisi obat akarbose (glucobay $\left.{ }^{\circledR}\right)$ 93,89 $\pm 0,02 \%$, sedangkan untuk infusa dari daun asam jawa segar dan infusa herbal benalu api segar nilai \% inhibisinya adalah negatif (-), berturut-turut ($176,57) \%$ dan $(-8,72) \%$.

Nilai \% inhibisi negatif menunjukkan bahwa kedua infusa ini tidak dapat menghambat aktivitas $\alpha$-amilase akan tetapi sebaliknya mempunyai kemampuan sebagai aktivator. Hal ini disebabkan karena absorbansi $\left(\mathrm{S}_{1-} \mathrm{S}_{0}\right)$ lebih besar dari absorbansi $\left(\mathrm{B}_{1}-\mathrm{B}_{0}\right)$. Sistim $\mathrm{S}_{1}$ berisi enzim ( $\alpha$-amilase), substrat (amilum) dan sampel ( infusa atau ekstrak etanol) yang diduga mampu menghambat aktivitas $\alpha$ amilase, sedangkan $\mathrm{B}_{1}$ hanya berisi enzim $\alpha$-amilase, substrat amilum, oleh karena itu apabila sampel mampu sebagai inhibitor maka absorbansi $\left(\mathrm{S}_{1-} \mathrm{S}_{0}\right)$ akan lebih 
kecil dari absorbansi $\left(\mathrm{B}_{1}-\mathrm{B}_{0}\right)$. Penambahan infusa maupun ekstrak etanol sebagai inhibitor terhadap aktivitas enzim $\alpha$-amilase akan memperkecil konsentrasi maltosa yang dihasilkan, sehingga kemampuan maltose untuk mereduksi DNS juga akan berkurang, akibatnya pembentukkan asam-3-amino-5-Dinitrosalisilat hasil reduksi warna orange kemerahan lebih pudar dan nilai absorbansi relatif lebih kecil

Pradono, et al di tahun 2008 menginformasikan bahwa daun asam jawa dapat digunakan sebagai penghambat lipase pankreas, yaitu enzim yang berperan dalam penguraian lipid untuk mengabsorpsi asam lemak, yang bertujuan untuk antiobesitas. Penyakit obesitas ini menyebabkan insulin yang dihasilkan pankreas tidak dapat membantu sel-sel tubuh untuk menyerap glukosa secara maksimal (Purwandari, 2014). Menurut Sumarjo, tahun 2009 menyatakan bahwa infusa daun asam jawa segar dan herba benalu api segar diduga mengandung ion-ion anorganik, ion logam atau kation yang dapat bertindak sebagai aktivator. Nilai \% aktivator dari kedua sampel tanaman tersebut yaitu sebesar $63,84 \%$ dan $6,65 \%$.

Infusa dapat menginhibisi enzim $\alpha$-amilase lebih baik daripada ekstrak etanol, hal ini diduga karena air memiliki kepolaran yang lebih tinggi dibandingkan etanol, sehingga senyawa-senyawa metabolit sekunder yang bersifat polar pada sampel tanaman akan terekstrak lebih banyak pada pelarut air, dengan adanya zat aktif yang lebih banyak pada pelarut air maka dapat meningkatkan kemampuan inhibisinya terhadap enzim $\alpha$-amilase. Data hasil analisis secara statistik menunjukkan bahwa \% inhibisi dari ke tiga infusa tidak berbeda secara signifikan dengan $\%$ inhibisi akarbose $(93.89 \pm 0.02)$, dengan kata lain ke tiga infusa ini berpotensi untuk dimanfaatkan sebagai obat alternatif penganti obat sintetik akarbose (glucobay®)

\section{SIMPULAN}

Persen inhibisi terhadap aktivitas enzim $\alpha$-amilase dari infusa herbal benalu api kering adalah $85,58 \pm 2,93 \%$, infusa herbal putri malu segar sebesar $87,40 \pm 1,81 \%$ dan infusa herbal putri malu kering sebesar 98,85 $\pm 0,66 \%$ tidak berbeda secara signifikan dengan inhibisi akarbose 93,89 $\pm 0,02 \%$. Ketiga (3) 
infusa ini berpotensi menghambat aktivitas enzim $\alpha$-amilase dan dapat dimanfaatkan sebagai obat alternatif penganti akarbose (glucobay®)

\section{UCAPAN TERIMA KASIH}

Terimakasih kepada program penelitian Desentralisasi Penelitian Hibah Bersaing Tahun Anggaran 2015 yang telah memberikan dana untuk pelaksanaan penelitian ini melalui Lembaga Penelitian dan Pengabdian Kepada Masyarakat (LPPM) Univertas Riau. Dengan No kontrak 574/UN.19.5.1.3/LT/2015

\section{DAFTAR PUSTAKA}

Dalimartha, S. 2007. Atlas Tumbuhan Obat Indonesia. Jilid 2. Trubus Agriwidya. Jakarta

Hakim L. 2011. Prinsip pengobatan Diabetes Mellitus Tipe 2 dari Penatalaksanaan Diabetes Mellitus Terpadu. FK.UI. Jakarta

Kementrian Kehutanan RI. 2010. Lokakarya Nasional Tanaman Obat Indonesia. Siaran Pers, S.376/PIK-1/2010. Jakarta

Kee, J. L., dan Hayes, E. R. 1996. Farmakologi Pendekatan Proses Approach. EGC. Jakarta

Pradono, D. I., Darusman, L. K., Susanti, A. 2008. Inhibisi Lipase Pankreas In Vitro Oleh Ekstrak Air dan Etanol Daun Asam Jawa (Tamarindus indica) dan Rimpang Kunci Pepet (Kaempferiae rotunda). Jurnal Natur Indonesia. 13 (2): 146-154

Purwandari, H. 2014. Hubungan Obesitas dengan Kadar gula Darah pada Karyawan di RS Tingkat IV Madiun. Efektor. 25 (1): 65-72

Robyt JF. 2005. Inhibition, Activation and Stabilizationof $\alpha$-amilase Family Enziymes. Biologia. 16: 17-26

Samuelsson, G. 2000. Drugs of Natural Orgin: ATextbook of Pharmacognosy $4^{\text {th }}$ ed. Apotekarsocieteten Swedia. 46-47.

Sastrohamidjojo dan Hardjono. 2005. Kimia Organik, Sterokimia, Lemak, dan Protein.UGM Press. Yogyakarta

Sumardjo, D. 2009. Pengantar Kimia. Buku Panduan Kuliah Mahasiswa Kedokteran dan program Strata I Fakultas Bioeksakta. EGC. Jakarta

Tampubolon, O. T. 1995. Tumbuhan Obat. Bharata.Jakarta .

Wijayakusuma, H. M. H. 2011. Atasi Kanker dengan Tanaman Obat. Puspa Swara. Jakarta 